\title{
CHARACTERIZATION OF Ni-P COATING PREPARED ON A WROUGHT AZ61 MAGNESIUM ALLOY VIA ELECTROLESS DEPOSITION
}

\author{
KARAKTERIZACIJA Ni-P PREVLEKE, PRIPRAVLJENE Z \\ NEELEKTRIČNO DEPOZICIJO NA KOVANI MAGNEZIJEVI \\ ZLITINI AZ61
}

\author{
Martin Buchtík ${ }^{1}$, Petr Kosár ${ }^{1}$, Jaromír Wasserbauer ${ }^{1}$, Pavel Doležal ${ }^{\mathbf{1 , 2}}$ \\ ${ }^{1}$ Brno University of Technology, Faculty of Chemistry, Purkyňova 464/118, 60200 Brno, Czech Republic \\ ${ }^{2}$ Brno University of Technology, Faculty of Mechanical Engineering, Technická 2896/2, 60200 Brno, Czech Republic \\ xcbuchtik@fch.vutbr.cz
}

Prejem rokopisa - received: 2017-03-08; sprejem za objavo - accepted for publication: 2017-04-20

doi:10.17222/mit.2017.029

\begin{abstract}
A low-phosphorous Ni-P coating was prepared on a wrought AZ61 magnesium alloy via electroless deposition for $1 \mathrm{~h}$ after an adequate substrate-surface pre-treatment. The prepared coating with a thickness of $10 \mu \mathrm{m}$ was characterized by the uniform distribution of $\mathrm{Ni}(95.4 \%$ mass fraction) and $\mathrm{P}$ (4.6\% mass fraction) in the cross-section. Microcavities present in the coating resulted in quite a low corrosion resistance of the coated magnesium alloy in a $0.1 \mathrm{M} \mathrm{NaCl}$ solution. On the other hand, the coating exhibits a high degree of adhesion, as evidenced by a scratch test, and significantly improves the AZ61 magnesium-alloy microhardness.

Keywords: electroless nickel, magnesium alloy, AZ61, characterization of Ni-P coatings

Malo porozna Ni-P prevleka je bila pripravljena na površini kovane AZ61 magnezijeve zlitine. Prevleka je bila pripravljena z enourno neelektrično depozicijo na predhodno ustrezno obdelani površini zlitine. Pripravljena prevleka debeline $10 \mu \mathrm{m}$ je imela $\mathrm{v}$ prečnem prerezu enakomerno porazdelitev $\mathrm{Ni}(95,4 \%$ masnih odstotkov) in $\mathrm{P}$ (4,6\% masnih odstotkov). Zaradi prisotnosti mikropraznin v izdelani prevleki je korozijska odpornost prevlečene magnezijeve zlitine v 0,1 M NaCl raztopini slaba. Preizkusi razenja prevleke pa so po drugi strani pokazali zelo dober oprijem izdelane prevleke s površino zlitine in znatno izboljšanje mikrotrdote AZ61 magnezijeve zlitine.

Ključne besede: brezelektrično nikljanje, magnezijeva zlitina, AZ61, karakterizacija Ni-P prevlek
\end{abstract}

\section{INTRODUCTION}

Due to their low density, magnesium alloys are ranked among the lightest constructional metallic materials. Magnesium alloys concurrently have a high specific strength, toughness and good casting properties. They find their application in the automotive and aerospace industry. ${ }^{1-4}$ A high chemical reactivity, low corrosion resistance and low hardness are their negative properties. ${ }^{4}$ Therefore, it is necessary to protect magnesium alloys against the effects of external environment. There are several ways of protecting magnesium alloys such as galvanic or electroless deposition of coatings, conversion coatings, organic coatings and varnishing.

Electroless-deposited Ni-P coatings improve the coated-material resistance to corrosive environments and material mechanical and wear resistance. Deposited Ni-P coatings have a higher corrosion resistance, physicomechanical and tribological properties compared to non-treated magnesium alloys. ${ }^{5-7}$ Generally, the industry identifies three groups of electroless Ni-P coatings according to their phosphorus contents. Low-phosphorus coatings contain 2-5\% mass fractions of phosphorus, medium-phosphorus Ni-P coatings contain 6-9 \% mass fractions of phosphorus and high-phosphorus Ni-P coatings contain $10-13 \%$ mass fractions of phosphorus. ${ }^{8}$ Low-phosphorus Ni-P coatings are predominantly used to increase the hardness of the coated substrate. ${ }^{1}$ In general, the hardness, crystallinity and density of electroless Ni-P coatings decrease with the increasing content of phosphorus in the coatings. However, the corrosion resistance of Ni-P coatings increases with the increasing content of phosphorus..$^{1,9}$

The hardness of deposited low-phosphorus Ni-P coatings can be additionally increased by heat treatment. ${ }^{5}$ During heat treatment, the deposited coating consisting of an amorphous Ni-P phase decomposes due to a gradual increase in the temperature to form crystalline particles of phosphide $\left(\mathrm{Ni}_{3} \mathrm{P}\right)$. Fine crystalline particles of phosphide $\left(\mathrm{Ni}_{3} \mathrm{P}\right)$ are formed simultaneously, predominantly in the form of precipitates. ${ }^{9}$ The highest value of the hardness of Ni-P coatings is reached after the heat treatment at $400{ }^{\circ} \mathrm{C}$ for $1 \mathrm{~h}$, when the hardness reaches a value of up to $1300 \mathrm{HV} .{ }^{10}$ The hardness of Ni-P coatings can also be increased by reducing the phosphorus content by changing the ratio of the components contained in the nickel bath and by changing the coating-process 
M. BUCHTÍK et al.: CHARACTERIZATION OF Ni-P COATING PREPARED ON A WROUGHT AZ61 ...

conditions. ${ }^{1}$ However, the Ni-P coating corrosion resistance increases with the increasing content of phosphorus. ${ }^{1}$ The phosphorus content in a deposited Ni-P coating can be controlled by adding suitable surfactants into the nickel bath. As mentioned in reference, ${ }^{11}$ an addition of SDS (sodium dodecyl sulfate) causes an increase in the phosphorus content from $6 \%$ to $9 \%$. It was observed that the hardness of the Ni-P coating increased with an increase in the SDS concentration up to its critical micelle concentration (CMC) and then decreased. The hardness of the Ni-P coating without a surfactant was $450 \mathrm{HV} 0.2$ and, in the presence of SDS, the hardness increased up to $685 \mathrm{HV} 0.2$. The change is due to the change in the coating crystalline structure. In the case of the absence of SDS, the structure of the Ni-P coating is purely crystalline. With an addition of SDS, the structure changes into a mixture of nanocrystalline and amorphous structure. At SDS concentrations higher than $\mathrm{CMC}$, the phosphorus content is $9-10 \%$. The same effect was observed for CTAB (cetyltrimethylammonium bromide). An addition of CTAB caused an increase of phosphorus in the deposited coating of 7.5-12\% and the hardness of the Ni-P coating increased up to $675 \mathrm{HV} 0.2$.

In general, the addition of some filler to the Ni-P coating matrix is another possible way to increase the hardness of Ni-P coatings. $\mathrm{SiC}, \mathrm{Al}_{2} \mathrm{O}_{3},{ }^{12-13} \mathrm{SiO}_{2}, \mathrm{TiO}_{2}{ }^{14-15}$ particles and carbon nanotubes can be used as a suitable filler for the Ni-P matrix, improving the coating properties.

The adhesion of the coatings to the substrate is significantly affected by appropriately selected pre-treatments of the substrate surface. ${ }^{13}$ The presented paper deals with the characterization of electroless-deposited Ni-P coatings prepared on an wrought AZ61 magnesium alloy. The influence of the coated-substrate pre-treatment and the coating chemical composition on the coating tribological properties and corrosion resistance was the main objective of the study. A $0.1 \mathrm{M} \mathrm{NaCl}$ solution was used for immersion tests to analyze the coated magnesium alloy corrosion resistance and corrosion mechanism.

\section{EXPERIMENTAL MATERIAL AND PROCEDURES}

\subsection{Experimental material}

Specimens of the wrought AZ61 magnesium alloy with dimensions of $20 \mathrm{~mm} \times 20 \mathrm{~mm} \times 0.8 \mathrm{~mm}$ were used as substrates for the deposition of the Ni-P coating. The EDS-measured chemical composition of the AZ61 magnesium alloy is shown in Table 1. The measured chemical composition corresponds to standard ASTM B107M. ${ }^{16}$ The microstructure of the alloy is shown in Figure 1. The microstructure was documented using a light optical microscope (LM) and the microstructural features were identified using a scanning electron microscope (SEM) with EDS. To reveal the magnesium alloy microstructure, ground and polished metallogra-
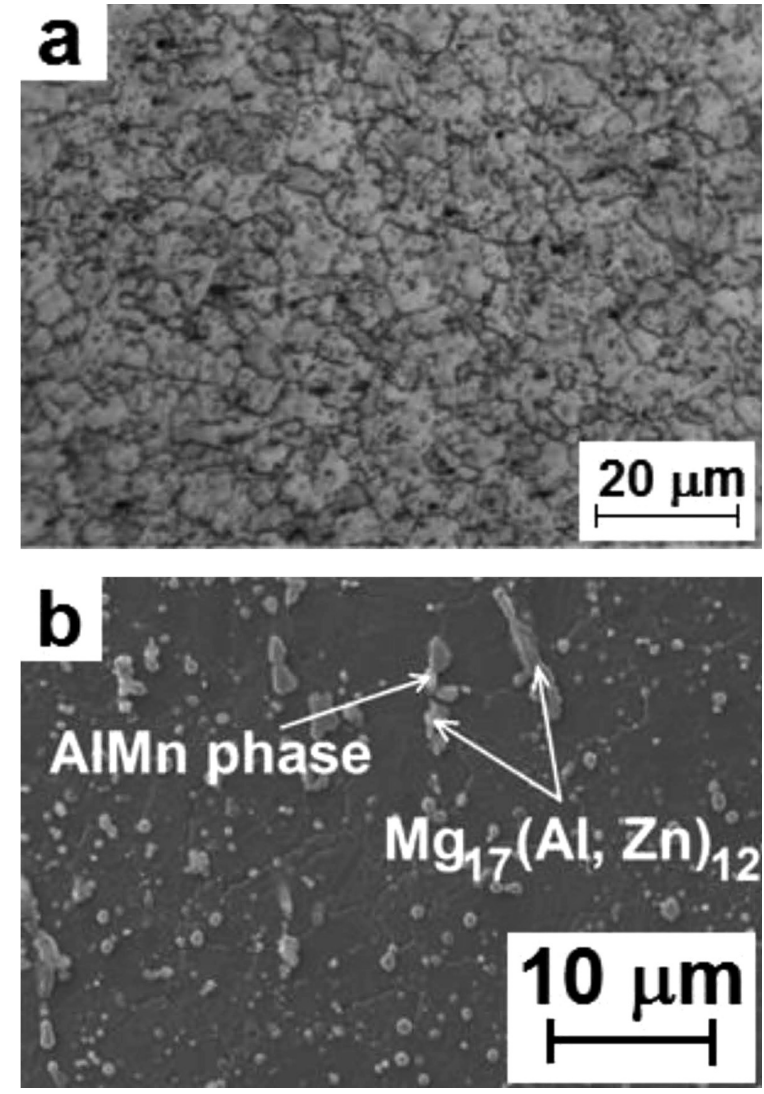

Figure 1: Microstructure of wrought AZ61 magnesium alloy, etched with picral etchant: a) structure of AZ61 magnesium alloy, LM; b) alloy phases, SEM

phic samples were poured into a picral etchant (consisting of $4.2 \mathrm{~g}$ picric acid, $10 \mathrm{~mL}$ acetic acid, $10 \mathrm{~mL}$ water and $70 \mathrm{~mL}$ ethanol) for $5 \mathrm{~s}$. The microstructure is formed by $\delta$ substitutional solid-solution grains (a solid solution of $\mathrm{Al}$ in $\mathrm{Mg}$ ) and $\gamma$ particles corresponding to the chemical composition of $\operatorname{Mg}_{17}(\mathrm{Al}, \mathrm{Zn})_{12}$. As shown in Figure 1b, the presence of AlMn-based intermetallic phases (apparently $\mathrm{Al}_{4} \mathrm{Mn}$ ) was also evident in the microstructure.

Table 1: Measured elemental composition of the uncoated wrought AZ61 magnesium alloy

\begin{tabular}{|c|c|c|c|c|c|c|c|c|c|}
\hline \multirow{2}{*}{ Alloy } & \multicolumn{8}{|c|}{ Elements $(w / \%)$} \\
\cline { 2 - 9 } & $\mathrm{Al}$ & $\mathrm{Zn}$ & $\mathrm{Mn}$ & $\mathrm{Si}$ & $\mathrm{Fe}$ & $\mathrm{Ni}$ & $\mathrm{Cu}$ & $\mathrm{Mg}$ & others \\
\hline \multirow{2}{*}{ AZ61 } & $5.8-$ & $0.4-$ & $0.15-$ & $\max$. & $\max$ & $\max$. & $\max$. & & max. \\
& 7.2 & 1.5 & 0.5 & 0.15 & 0.005 & 0.005 & 0.05 & bal. & 0.3 \\
\hline
\end{tabular}

\subsection{Deposition of the Ni-P coating}

Before the Ni-P coating deposition, a specific pretreatment was required to reach the adequate surface roughness and activity. The samples of the AZ61 magnesium alloy were ground using SiC paper no. 1200. Next, the samples were degreased in an alkaline degreasing bath containing soil-releasing agents. The following pickling in an acid pickling bath was performed to activate the surface with partial etching (removing of the 
oxide layer). Rinsing the samples with distilled water and isopropanol and drying them with a stream of hot air were performed between the steps of the pre-treatment.

The electroless Ni-P coating deposition, following the sample-surface pre-treatment, proceeded for $60 \mathrm{~min}$. The electroless nickel bath was composed by a nickel source $\left(\mathrm{NiSO}_{4} \cdot 6 \mathrm{H}_{2} \mathrm{O}\right)$, a reducing agent $\left(\mathrm{NaH}_{2} \mathrm{PO}_{2} \cdot \mathrm{H}_{2} \mathrm{O}\right)$, a complexing agent and an $\mathrm{H}_{2} \mathrm{PO}_{2}^{-}$activating substance. The samples were kept in the middle of the bath to ensure a uniform coating formation.

\subsection{Characterization of the Ni-P coating}

The microhardness of the deposited Ni-P coating was carried out using a Vickers microhardness tester LECO AMH43. Loading of $25 \mathrm{~g}$ for $10 \mathrm{~s}$ was used for the indentation according to the standard. ${ }^{17}$ To obtain the average value, ten indentations were performed on the coating cross-section. The average thickness of the deposited Ni-P coating used for microhardness testing was about $30 \mu \mathrm{m}$.

The physicochemical properties of the deposited Ni-P coating were evaluated using a CSM Instruments REVETEST scratch tester with the progressive-load-type method and a Rockwell diamond indenter with the top angle of $120^{\circ}$ and the top radius of $200 \mu \mathrm{m}$. For the evaluation of the physicochemical properties, the surface of the substrate was polished to the roughness of $R_{\mathrm{a}} \approx 0.25 \mu \mathrm{m}$ using diamond pastes during the pre-treatment after the grinding. The friction force, the friction coefficient, the penetration depth and the acoustic emission were recorded along with the adhesion during the scratch test. The applied normal force was set in a range of 1-20 N. The speed of the indenter was $1.58 \mathrm{~mm}$ $\mathrm{min}^{-1}$ and the total length of the trace was $3 \mathrm{~mm} .{ }^{18}$

A Zeiss Evo LS-10 scanning electron microscope (SEM) equipped with an EDS Oxford Instruments Xmax $80 \mathrm{~mm}^{2}$ detector and the AZtec software was used to determine the average contents of nickel and phosphorus in the deposited Ni-P coatings. SEM observations were also used to evaluate the mechanism of the corrosion degradation of the magnesium substrate and the deposited Ni-P coating after an exposure to $0.1 \mathrm{M} \mathrm{NaCl}$.

For the evaluation of the mechanism of the corrosion degradation of the magnesium substrate and the deposited Ni-P coating, the samples were immersed into a 0.1 $\mathrm{M}$ solution of $\mathrm{NaCl}$ for $20 \mathrm{~min}$. After this time, the surface of a sample was analyzed using the scanning electron microscope and the mechanism of corrosion degradation was determined on the cross-section of the sample.

\section{RESULTS AND DISCUSSION}

\subsection{Characterization of the deposited Ni-P coatings}

Uniform Ni-P coatings were deposited on the AZ61 magnesium alloy substrate. Figure 2a shows the nodular
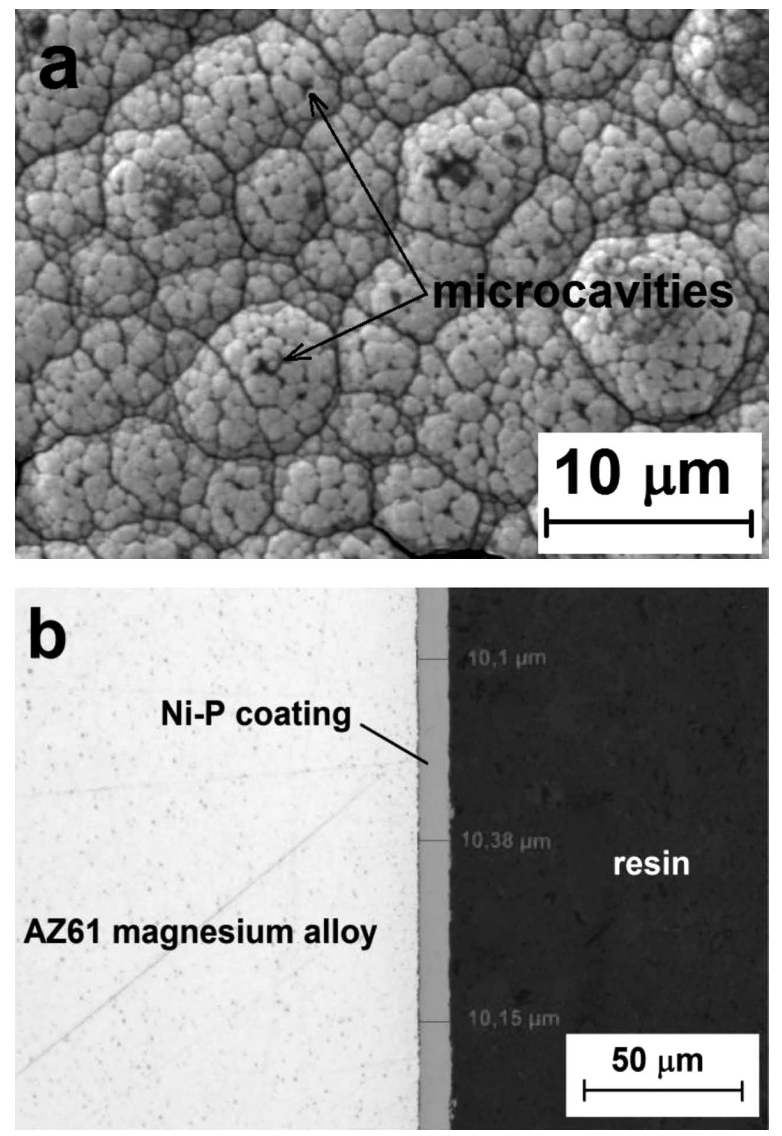

Figure 2: Microstructure of Ni-P coating: a) surface morphology of Ni-P coating, b) cross-section morphology of Ni-P coating on AZ61 magnesium alloy

structure of the Ni-P coating with a typical cauliflowerlike pattern. Between these nodular cusps, a certain amount of microcavities is present. These microcavities are nucleation sites for micropitting in the case of material exposure to a corrosive environment. However, no macrodefects were observed in the deposited Ni-P coatings, neither at the Ni-P/substrate interface. Figure 2b shows the cross-section morphology of the deposited $\mathrm{Ni}-\mathrm{P}$ coating. It shows that the $\mathrm{Ni}-\mathrm{P}$ coating is uniform and compact. The average thickness of the deposited Ni-P coating used for the microhardness testing was about $30 \mu \mathrm{m}$ and the average thickness of the deposited Ni-P coating used for the EDS analysis and the scratch test was about $10 \mu \mathrm{m}$.

Using the EDS analysis, it was determined that the content and distribution of individual components in the deposited Ni-P coating were homogeneous throughout the entire cross-section (Figure 3). The analysis showed that the nickel content in the deposited Ni-P coating was $95.4 \pm 0.1 \%$ mass fraction and the phosphorus content was $4.6 \pm 0.1 \%$ mass fraction. Based on references, ${ }^{8,10}$ this coating can be classified as a low-phosphorus Ni-P coating. The homogenous distribution of individual elements in the coating is a sign of a continual coating growth. 

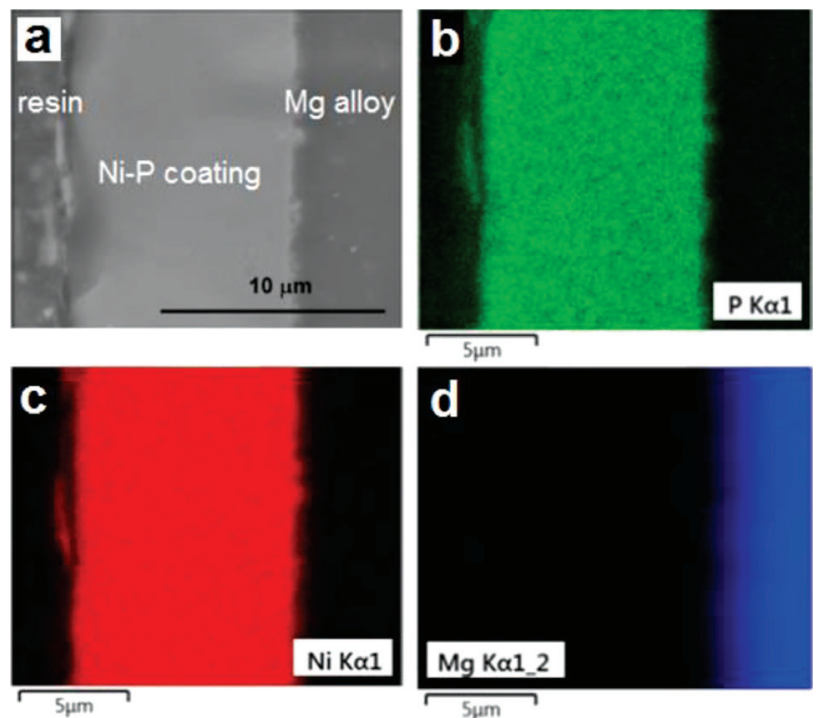

Figure 3: Mapping of Ni-P coating on AZ6 alloy: a) structure of Ni-P coating, b) phosphorus, c) nickel, d) magnesium

\subsection{Mechanical and physicochemical properties of the deposited Ni-P coating}

The resulting average microhardness value of the prepared electroless-deposited low-phosphorous $\mathrm{Ni}-\mathrm{P}$ coating is $700 \pm 40 \mathrm{HV} 0.025$, as measured on 10 random places on the coating cross-section. The microhardness of the plain magnesium substrate is $79 \pm 6 \mathrm{HV} 0.025$, so the microhardness of the Ni-P coating is around nine times higher than that of the AZ61 magnesium substrate.

The obtained value is higher when compared to the microhardness of the coating reported on in reference ${ }^{19}$. On the other hand, a positive influence of the filler addition and heat treatment on the coating microhardness was observed in reference. ${ }^{19}$ An increase in the microhardness from $380 \pm 10 \mathrm{HV} 0.1$ to $540 \pm 10 \mathrm{HV} 0.1$ was observed when adding $\mathrm{SiO}_{2}$ nanoparticles to the Ni-P coating $^{19}$; however, this value is still lower when compared to the presented coating. The microhardness of the electroless-deposited composite coating reported on in reference ${ }^{19}$ increased to $970 \pm 10 \mathrm{HV} 0.1$ when applying a heat treatment to the coated component at $400{ }^{\circ} \mathrm{C}$.

A similar effect was observed in the work reported in reference ${ }^{20}$ where the hardness of the plain Ni-P coating reached a value of $608 \pm 12 \mathrm{HV}$. With the addition of a $\mathrm{TiO}_{2}$ colloidal solution to the nickel bath, followed by a co-deposition of $\mathrm{TiO}_{2}$ particles into the Ni-P coating, the hardness value of the $\mathrm{Ni}-\mathrm{P} / \mathrm{TiO}_{2}$ composite coating increased to $685 \pm 18 \mathrm{HV}$, which is comparable with the presented coating. The increase in the hardness of the deposited $\mathrm{Ni}-\mathrm{P} / \mathrm{TiO}_{2}$ composite coating to $1325 \pm 40 \mathrm{HV}$ was observed by following the application of a heattreatment. ${ }^{20}$

The obtained values of critical normal forces $L_{\mathrm{c} 1}$ and $L_{\mathrm{c} 2}$ and adequate values of friction forces $F_{\mathrm{t} 1}$ and $F_{\mathrm{t} 2}$ at normal forces $L_{\mathrm{c} 1}$ and $L_{\mathrm{c} 2}$, respectively, are shown in
Table 2. The record of the scratch test of the Ni-P coating on the AZ61 magnesium alloy is shown in Figure 4. Details of the Ni-P coating on the AZ61 magnesium alloy after the scratch test for normal forces $L_{\mathrm{c} 1}$ and $L_{\mathrm{c} 2}$ are shown in Figures $\mathbf{5} \mathbf{a}$ and $\mathbf{5 b}$, respectively.

The determined value of critical normal force $L_{\mathrm{c} 1}$ was 6.9 N. The formation of oblique and parallel cracks were observed at $L_{\mathrm{cl}}$, Figure 5a. The determined value of critical normal force $L_{\mathrm{c} 2}$ was $11.9 \mathrm{~N}$. The formation of transverse arch cracks was observed at $L_{\mathrm{c} 2}$, Figure $\mathbf{5 b}$. Ductile failure of the coating due to the internal tensile stresses occurs during the scratch test.

Table 2: Values of critical normal forces and friction forces of Ni-P coatings and a comparison of these values with the published data

\begin{tabular}{|c|c|c|c|c|c|c|}
\hline Lit. & $\begin{array}{c}\text { Sub- } \\
\text { strate }\end{array}$ & Coating & $L_{\mathrm{c} 1}(\mathrm{~N})$ & $L_{\mathrm{c} 2}(\mathrm{~N})$ & $\begin{array}{c}F_{\mathrm{t} 1} \text { at } L_{\mathrm{c} 1} \\
(\mathrm{~N})\end{array}$ & $\begin{array}{c}F_{\mathrm{t} 2} \text { at } L_{\mathrm{c} 2} \\
(\mathrm{~N})\end{array}$ \\
\hline $\begin{array}{c}\text { This } \\
\text { work }\end{array}$ & $\mathrm{AZ61}$ & $\mathrm{Ni}-\mathrm{P}$ & 6.9 & 11.9 & 0.8 & 2.2 \\
\hline$(21)$ & $\mathrm{AZ31}$ & $\mathrm{Ni}-\mathrm{P}$ & 7.3 & 12.3 & 1.1 & 2.6 \\
\hline$(2)$ & $\mathrm{AZ91}$ & $\mathrm{Ni}-\mathrm{P}$ & - & $17.6\left(L_{\mathrm{c}}\right)$ & - & - \\
\hline$(23)$ & $\mathrm{AZ61}$ & $\mathrm{PEO}$ & $\begin{array}{c}2.69 \pm 0 \\
.10\end{array}$ & - & - & - \\
\hline$(24)$ & AZ61 & $\begin{array}{c}\mathrm{Ti} / \mathrm{Ti} \\
(\mathrm{C}, \mathrm{N}) / \\
(\mathrm{TiAl}) \mathrm{N}\end{array}$ & 3 & 10 & - & - \\
\hline
\end{tabular}

Comparing critical loads $L_{\mathrm{c} 1}$ and $L_{\mathrm{c} 2}$ of the experimental Ni-P coating deposited on the AZ61 magnesium alloy with the Ni-P coating deposited on the AZ31 magnesium alloy from ${ }^{21}$, it became clear that the Ni-P coating on the AZ61 magnesium alloy achieved lower critical values $L_{\mathrm{c} 1}$ and $L_{\mathrm{c} 2}$. Oblique, parallel and transverse arch cracks were also observed on the Ni-P coating on the AZ31 magnesium alloy. ${ }^{21}$ This effect can be attributed to a slight difference between the methods of the pre-treatment of the magnesium substrate before the deposition process.

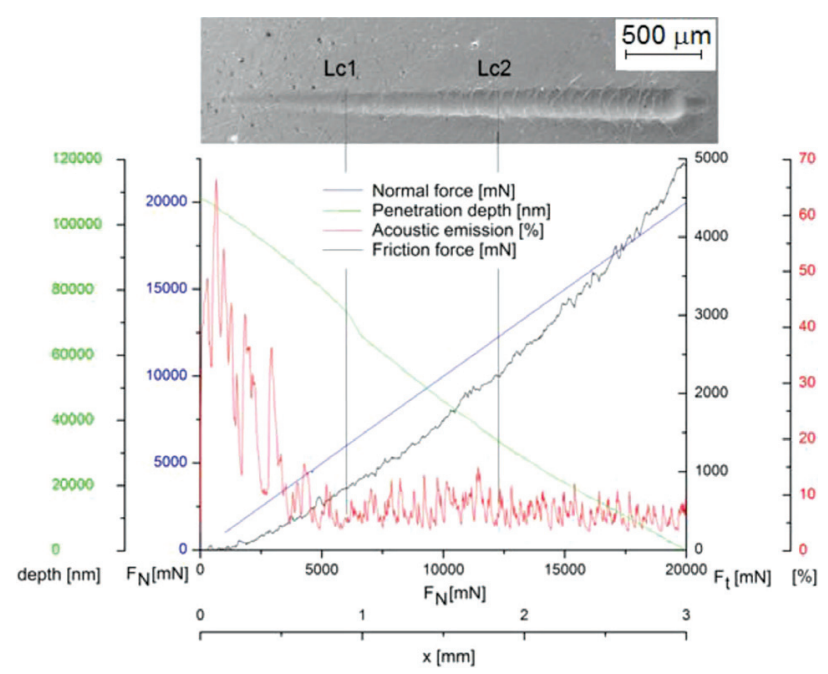

Figure 4: Evaluation of scratch tests for Ni-P coating on AZ61 magnesium alloy 
The adhesion of the deposited heat-treated Ni-P coating prepared on the AZ91 magnesium alloy was evaluated in reference. ${ }^{2}$ The first cracks on the heat-treated Ni-P coating deposited on the AZ91 magnesium alloy were observed at a load of $17.6 \mathrm{~N}$ and their characteristics were the same for all the heat-treated samples. However, the character of the cracks is slightly different compared to the experimental samples (Ni-P on AZ61) due to the heat treatment of the Ni-P coating. Heattreated coatings are more brittle compared to the nontreated coatings. ${ }^{1}$ Moreover, it was observed that the abundance of cracks increased with the increasing applied load.

In literature ${ }^{2}$, critical load value $L_{\mathrm{c}}$, where the first cracks were observed, is higher than that of the Ni-P coatings deposited on the AZ61 magnesium alloy (Table 2) and the samples of AZ31 described in reference ${ }^{21}$. This fact can be attributed to several factors. The progressive-load-type method of the scratch test was chosen for the evaluation of the adhesion of the experimental $\mathrm{Ni}-\mathrm{P}$ coating on an AZ61 alloy and the Ni-P coating on an AZ31 alloy in ${ }^{21}$. However, the constant-load-type method of the scratch test was chosen for the evaluation of the adhesion of a heat-treated Ni-P coating in literature $^{2}$. Moreover, the initial load for the evaluation of the heat-treated Ni-P coatings on the AZ91 magnesium alloy was determined to be $8.80 \mathrm{~N}$ and the load was increased five times to $44.0 \mathrm{~N}$. The heat treatment can affect the
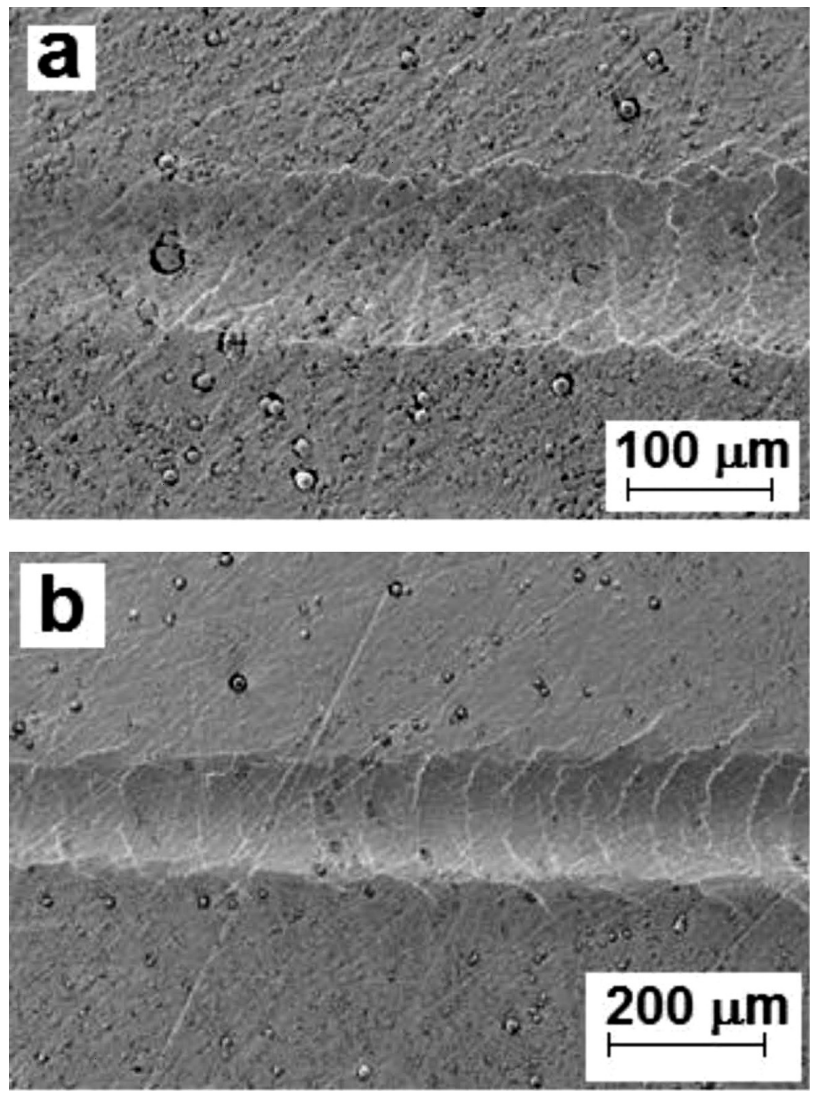

Figure 5: Details of Ni-P coating after scratch tests: a) $L_{\mathrm{c} 1}$, b) $L_{\mathrm{c} 2}$ adhesion of the coating to the substrate. As indicated in literature $^{22}$, the creation of Al-Ni intermetallic phases can significantly reduce the adhesion of Ni-P coatings to the AZ91 magnesium alloy after the heat treatment. However, this effect was not observed in the research from reference ${ }^{2}$. This can be attributed to the fact that the presence of these phases is limited to small areas of the $\gamma$ phase $\left(\mathrm{Mg}_{17} \mathrm{Al}_{12}\right)$ present on a substrate surface. The content of the $\gamma$ phase is dependent on the Al content in the substrate. Clearly, a low amount of Al in AZ91 used in the research from reference ${ }^{2}$ did not have a detrimental effect on the coating adhesion.

As shown in Table 2, it was observed that the adhesion of the PEO (plasma electrolytic oxidation) coating on the AZ61 magnesium alloy mentioned in reference $^{23}$ is lower with respect to the Ni-P coatings deposited on the AZ61 magnesium alloy in this work. In particular, a significantly lower value of critical load $L_{\mathrm{c} 1}$ resulting in coating damage was measured in the research from literature ${ }^{23}$, with respect to the present work.

It can be noted that the deposited Ni-P coating showed a higher adhesion to the magnesium-alloy substrate with respect to the PEO or plasmatic composite coatings. ${ }^{24}$ These composite coatings and plasma-deposited layers are more brittle than the deposited coatings. In addition, the adhesion of coatings to the substrate is negatively affected by the stresses at the matrix/filler interface created during the coating formation. ${ }^{25}$
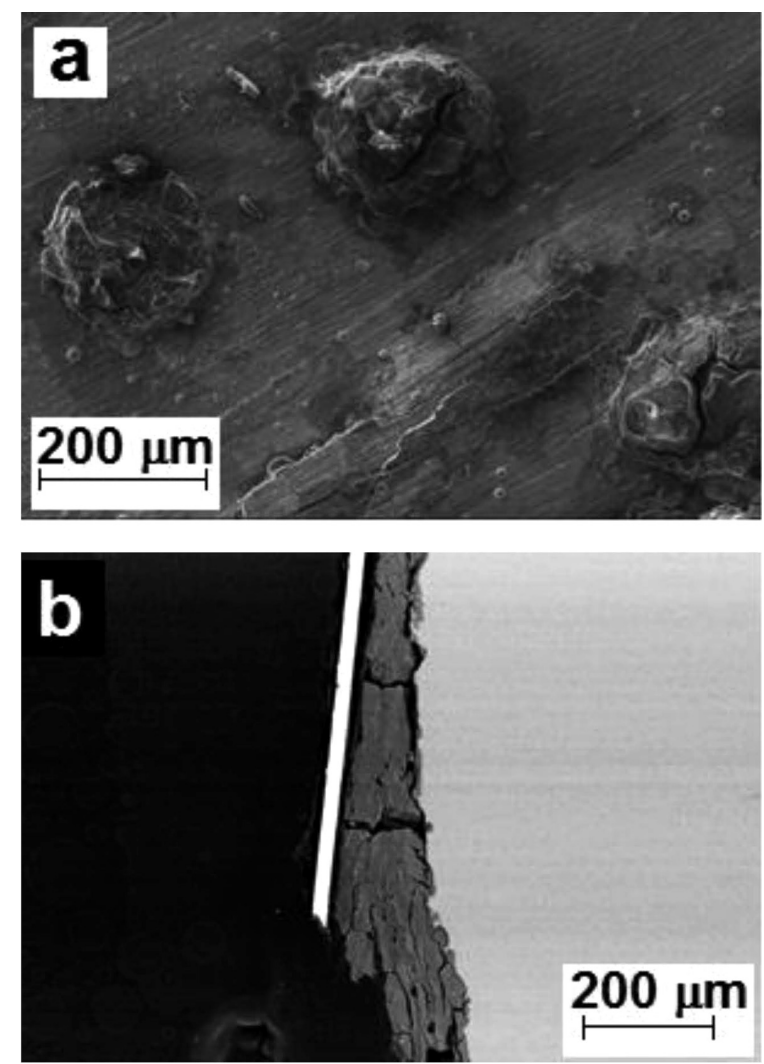

Figure 6: Ni-P coating on AZ61 magnesium alloy after an exposure to $0.1 \mathrm{M} \mathrm{NaCl}$ : a) surface, b) cross-section 


\subsection{Exposure of the samples to a corrosive environ- ment}

Figure 6 shows a corrosion degradation of the AZ61 magnesium alloy with the Ni-P coating after an exposure to a $0.1 \mathrm{M} \mathrm{NaCl}$ solution for $20 \mathrm{~min}$. The low-phosphorus coatings are characterized by a higher hardness and crystallinity but also by a lower corrosion resistance when compared to the high-phosphorous Ni-P coatings. ${ }^{10}$

The deposited Ni-P coating was characterized by a structure with nodular cusps (Figure 2a). An imperfect nickel deposition may occur among these cusps, causing the Ni-P coating to have a certain amount of microcavities in its volume. These microcavities are the nucleation sites for a corrosion attack and micropitting in the case of an exposure to a corrosive environment. The transport of corrosive agents to the surface of the magnesium substrate occurs through these microcavities. The corrosion process starts at the magnesium substrate/Ni-P coating interface. Chemical reactions occur due to the interaction between the corrosive agents and the magnesium-alloy substrate. The formed corrosion products accumulating on the magnesium alloy under the Ni-P coating lead to a local destruction of the coating as shown in Figure 6. An EDS analysis revealed that these corrosion products are predominantly formed by the oxides and chlorides of magnesium.

The presence of microcavities in Ni-P coatings can be eliminated or removed by adding suitable surfactants to the nickel bath. Such suitable surfactants can be sodium dodecyl sulfate, sodium benzenesulfonate or CTAB. ${ }^{11,26-27}$

\section{CONCLUSION}

An electroless-deposited low-phosphorous Ni-P coating was successfully prepared on a wrought AZ61 magnesium alloy by applying a pre-treatment process. The deposited Ni-P coating was characterized in terms of elemental composition, mechanical and physicochemical properties.

In terms of the chemical composition, the deposited $10-\mu \mathrm{m}$-thick Ni-P coating treated for $1 \mathrm{~h}$ shows a high degree of homogeneity over the entire cross-section with a phosphorus content of $4.6 \pm 0.1 \%$ and a nickel content of $95.4 \pm 0.1 \%$. The microhardness of the deposited Ni-P coating reached a value of $700 \pm 40 \mathrm{HV} 0.025$. In terms of physicochemical properties, the deposited Ni-P coating was characterized by a high degree of adhesion. The adhesion was determined from the corresponding critical normal forces $L_{\mathrm{c} 1}(6.9 \mathrm{~N})$ and $L_{\mathrm{c} 2}(11.9 \mathrm{~N})$. The mechanism of corrosion degradation of Ni-P applied on the AZ61 magnesium alloy substrate was determined based on a metallographic observation of a corrosion attack with the subsequent degradation of the magnesium substrate due to the microcavities present in the coating, allowing the contact of the corrosive environment with the substrate.

\section{Acknowledgement}

This work was supported by project Nr. LO1211, Materials Research Centre at FCH BUT - Sustainability and Development (National Programme for Sustainability I, Ministry of Education, Youth and Sports).

\section{REFERENCES}

${ }^{1}$ W. Riedel, ASM International, Electroless Nickel Plating, Reprint ed., Finishing Publications, London 1991, 320

${ }^{2}$ M. Novák, D. Vojtěch, P. Novák, T. Vítů, Tribological properties of heat-treated electroless Ni-P coatings on AZ91 alloy, Appl. Surf. Sci., 257 (2011) 23, 9982-9985, doi:10.1016/j.apsusc.2011.06.119

${ }^{3}$ E. Altuncu, H. Alanyali, The applicability of sol-gel oxide films and their characterization on a magnesium alloy, Mater. Tehnol., 48 (2014) 2, 289-292

${ }^{4}$ M. Madaj, M. Greger, V. Karas, Magnesium-alloy die forgings for automotive applications, Mater. Tehnol., 49 (2015) 2, 267-273, doi:10.17222/mit.2013.174

${ }^{5}$ B. Panja, S. K. Das, P. Sahoo, Tribological Behavior of Electroless Ni-P Coating in Brine Environment, J. Inst. Eng., 95 (2014) 2, 153-159, doi:10.1007/s40033-014-0041-9

${ }^{6}$ A. Grosjean, M. Rezrazi, P. Bercot, M. Tachez, Adaptation of a mathematical model to the incorporation of silicon carbide particles in an electroless nickel deposit, Met. Finish., 96 (1998) 4, 14-17, doi:10.1016/S0026-0576(97)86615-9

${ }^{7}$ A. I. Aydeniz, A. Göksenli, G. Dil, F. Muhaffel, C. Calli, B. Yüksel, Electroless Ni-B-W coatings for improving hardness, wear and corrosion resistance, Mater. Tehnol., 47 (2013) 6, 803-806

${ }^{8}$ R. Parkinson, Properties and applications of electroless nickel, Nickel Development Institute, 1997, 37

${ }^{9}$ M. Buchtík, P. Kosár, J. Wasserbauer, M. Zmrzlý, Electroless Deposition of Ni-P/SiO2 Composite Coating, Acta U. Agr. Silvi. Mendel. Brun., 64 (2016) 5, 1459-1464, doi:10.11118/actaun201664051459

${ }^{10}$ G. O. Mallory, J. B. Hajdu, Electroless Plating: Fundamentals and Applications, Reprint ed., NY, Knoyes Publications/William Andrew Publishing, Norwich 2009, 575

${ }^{11}$ R. Elansezhian, B. Ramamoorthy, P. K. Nair, Effect of surfactants on the mechanical properties of electroless (Ni-P) coating, Surf. Coat. Tech., 203 (2008) 5-7, 709-712, doi:10.1016/j.surfcoat.2008.08.021

${ }^{12}$ C. Li, Y. Wang, Z. Pan, Wear resistance enhancement of electroless nanocomposite coatings via incorporation of alumina nanoparticles prepared by milling, Mater. Design., 47 (2013), 443-448, doi:10.1016/j.matdes.2012.12.021

${ }^{13}$ Y. Xin, K. Huo, T. Hu, G. Tang, P. K. Chu, Mechanical properties of A12O3/Al bi-layer coated AZ91 magnesium alloy, Thin Solid Films, 517 (2009) 17, 5357-5360, doi:10.1016/j.tsf.2009.03.101

${ }^{14}$ E. Georgiza, J. Novakovic, P. Vassiliou, Characterization and corrosion resistance of duplex electroless $\mathrm{Ni}-\mathrm{P}$ composite coatings on magnesium alloy, Surf. Coat. Tech., 232 (2013), 432-439, doi:10.1016/j.surfcoat.2013.05.047

${ }^{15} \mathrm{~S}$. Afroukhteh, C. Dehghanian, M. Emamy, Preparation of the Ni-P composite coating co-deposited by nano TiC particles and evaluation of its corrosion property, Appl. Surf. Sci., 258 (2012) 7, 2597-2601, doi:10.1016/j.apsusc.2011.10.101

${ }^{16}$ ASTM B107 / B107M-13 - Standard Specification for Magnesium-Alloy Extruded Bars, Rods, Profiles, Tubes, and Wire, ASTM International, West Conshohocken

${ }^{17}$ ISO 6507-1:2005(E) - Metallic materials, Vickers hardness test Part 1: Test method, Prepared by Technical Committee ISO/TC 164, Geneva

${ }^{18}$ ASTM C1624 - 05(2010) - Standard Test Method for Adhesion Strength and Mechanical Failure Modes of Ceramic Coatings by Quantitative Single Point Scratch Testing, ASTM International, West Conshohocken 


\section{MATERIALI IN TEHNOLOGIJE/MATERIALS AND TECHNOLOGY (1967-2017) - 50 LET/50 YEARS}

\section{BUCHTÍK et al.: CHARACTERIZATION OF Ni-P COATING PREPARED ON A WROUGHT AZ61 ...}

${ }^{19}$ A. Sadeghzadeh-Attar, G. Ayubikia, M. Ehteshamzadeh, Improvement in tribological behavior of novel sol-enhanced electroless Ni-P-SiO2 nanocomposite coatings, Surf. Coat. Tech., 307 (2016), 837-848, doi:10.1016/j.surfcoat.2016.10.026

${ }^{20}$ X. Wu, J. Mao, Z. Zhang, Y. Che, Improving the properties of $211 Z$ $\mathrm{Al}$ alloy by enhanced electroless $\mathrm{Ni}-\mathrm{P}-\mathrm{TiO} 2$ nanocomposite coatings with TiO2 sol, Surf. Coat. Tech., 270 (2015), 170-174, doi:10.1016/ j.surfcoat.2015.03.006

${ }^{21}$ M. Buchtík, P. Kosár, J. Wasserbauer, P. Doležal, Characterization of $\mathrm{Ni}-\mathrm{P}$ coating prepared via electroless deposition on wrought AZ31 magnesium alloy, Corros. Mater. Pr., 61 (2017) 1, doi:10.1515/ kom-2016-0026

${ }^{22}$ M. Novák, D. Vojtěch, T. Vítů, Influence of heat treatment on tribological properties of electroless Ni-P and Ni-P-A12O3 coatings on Al-Si casting alloy, Appl. Surf. Sci., 256 (2010) 9, 2956-2960, doi:10.1016/j.apsusc.2009.11.057

${ }^{23}$ A. Němcová, P. Skeldon, G. E. Thompson, S. Morse, J. Čížek, B. Pacal, Influence of plasma electrolytic oxidation on fatigue performance of AZ61 magnesium alloy, Corros. Sci., 82 (2014), 58-66, doi:10.1016/j.corsci.2013.12.019
${ }^{24}$ T. Tańsky, Characteristics of Hard Coatings on AZ61 Magnesium Alloys, J. Mech. Eng., 59 (2013) 3, 165-174, doi:10.5545/sv-jme. 2012.522

${ }^{25}$ K. Tohgo, G. J. Weng, A Progressive Damage Mechanics in Particle-Reinforced Metal-Matrix Composites Under High Triaxial Tension, J. Eng. Mater. Technol., 116 (1994) 3, 414-420, doi: $10.1115 / 1.2904307$

${ }^{26}$ R. Elansezhian, B. Ramamoorthy, P. K. Nair, The influence of SDS and CTAB surfactants on the surface morphology and surface topography of electroless Ni-P deposits, J. Mater. Process. Tech., 209 (2009) 1, 233-240, doi:10.1016/j.jmatprotec.2008.01.057

${ }^{27}$ B.-H. Chen, L. Hong, Y. Ma, T.-M. Ko, Effects of Surfactants in an Electroless Nickel-Plating Bath on the Properties of Ni-P Alloy Deposits, Ind. Eng. Chem. Res., 41 (2002) 11, 2668-2678, doi:10.1021/ie0105831 